\title{
Estradiol-17ß regulates vascular endothelial growth factor and Bcl-2 expression in HHUA cells
}

\author{
XU ZHI, KEN-ICHI HONDA, TOSHIYUKI SUMI, TOMOYO YASUI, \\ HIROYUKI NOBEYAMA, HIROYUKI YOSHIDA and OSAMU ISHIKO \\ Department of Obstetrics and Gynecology, Osaka City University Graduate School of Medicine, \\ 1-4-3 Asahimachi, Abeno-ku, Osaka 545-8585, Japan
}

Received June 27, 2007; Accepted August 22, 2007

\begin{abstract}
HHUA, a rare endometrial cancer cell line expressing the estrogen receptor (ER), was adopted to investigate the expression of vascular endothelial growth factor (VEGF), erythropoietin (Epo), Bcl-2 and p53 under the administration of estradiol-17ß (E2). Based on quantitative real-time reverse transcription polymerase chain reaction assays, both VEGF and Bcl-2 mRNA levels decreased in a dose-dependent manner, although VEGF levels were increased in a time-dependent manner; no significant change was found for Epo and p53. An immunocytochemical study also showed the suppressed expression of VEGF and Bcl-2 under E2 induction. Both ER $\alpha$ and $\mathrm{ER} \beta \mathrm{mRNAs}$ were detected in HHUA cells with ERß expression being predominantly higher than that of ER $\alpha$, which is the converse of the pattern seen in normal endometria. The present study shows the E2-downregulated expression of VEGF and Bcl-2, and reveals a disrupted balance of ER $\alpha$ and ERß expression, which should be taken into consideration to understand the particularity of E2-regulated gene expression in HHUA cells.
\end{abstract}

\section{Introduction}

Endometrial cancer (EC) is the most common malignant tumor of the female genital system in developed countries; however, the molecular mechanisms underlying EC remain unclear.

Without an adequate vascular supply, solid tumors can grow only to a critical size of $1-2 \mathrm{~mm}$ (or $\sim 10^{6}$ cells), primarily due to a lack of oxygen and nutrients $(1,2)$. Therefore, angiogenesis is regarded to play a pivotal role in tumor growth and metastasis. In this respect, vascular endothelial growth factor (VEGF), which could activate vascular endothelial cell growth

Correspondence to: Dr Xu Zhi, Department of Obstetrics and Gynecology, Osaka City University Graduate School of Medicine, 1-4-3 Asahimachi, Abeno-ku, Osaka 545-8585, Japan

E-mail:m1151239@med.osaka-cu.ac.jp

Key words: HHUA, vascular endothelial growth factor, erythropoietin, Bcl-2, p53, estrogen receptor $\alpha$, estrogen receptor $\beta$, estradiol$17 ß$, endometrial cancer and increase blood vessel permeability (3), is regarded as a key mediator of angiogenesis in cancers (2). Previous studies on the regulation of VEGF in EC have shown that VEGF gene expression is hormone dependent, but contradictory results have been reported (4-6). In addition, erythropoietin (Epo), a glycoprotein hormone stimulator of erythropoiesis, has attracted attention for its angiogenic function (7). Epo was traditionally considered to be expressed in fetal liver and adult kidney (8) until it was found in other sites, including the normal human endometrium and EC tissue (9-12), and was thought to be involved in angiogenesis in the uterus and ECs $(9,12)$. Studies on normal uterus suggested a hormone-dependent Epo expression $(9,10)$, but there have been no in vitro investigations on Epo expression under estrogen stimulation in ECs.

On the other hand, tumor growth is dependent not only on the rate of cell proliferation, but also on the rate of cell death. This may be reflected in the expression of the apoptosis-related genes $\mathrm{Bcl}-2$ and $\mathrm{p} 53 . \mathrm{Bcl}-2$ is a proto-oncogene initially described in $\mathrm{t}(14 ; 18)$ translocation follicular lymphomas (13) and has been shown to prolong cell survival by preventing apoptosis (14). Hormone-dependency of Bcl-2 expression in normal endometrium and EC has been reported by immunohistochemical studies $(15,16)$; however, investigations of $\mathrm{Bcl}-2$ expression in vitro are rare. Moreover, an inverse interaction between the Bcl-2 gene and tumor suppressor p53 gene has been suggested in some malignant diseases $(17,18)$.

Besides the above-mentioned factors related to the regulation of tumor growth and death, the expression of the estrogen receptor (ER) should also be considered when investigating estrogen action in ECs. HHUA, a rare EC cell line expressing the ER, established from a well-differentiated endometrial adenocarcinoma by Ishiwata et al (19), was adopted in this study to investigate the regulation of estradiol$17 ß$ (E2) on the expression of VEGF, Epo, Bcl-2 and p53, and the expression status of ERs in HHUA cells.

\section{Materials and methods}

Cell line and cell culture. HHUA cells were obtained from Riken Cell Bank (Tsukuba, Japan), and cultured at $37^{\circ} \mathrm{C}$ in humidified air containing $5 \% \mathrm{CO}_{2}$. Cells for experimental treatments were plated in 35-mm tissue culture dishes (Becton, Dickinson and Company, Franklin Lakes, NJ, USA) in phenol red-free medium (D-MEM/F-12; Gibco BRL, Grand Island, 
(A)

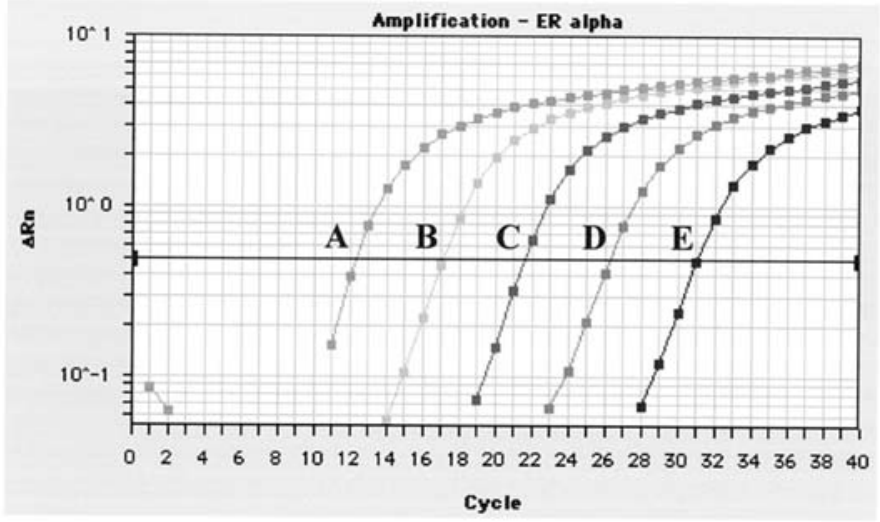

(C)

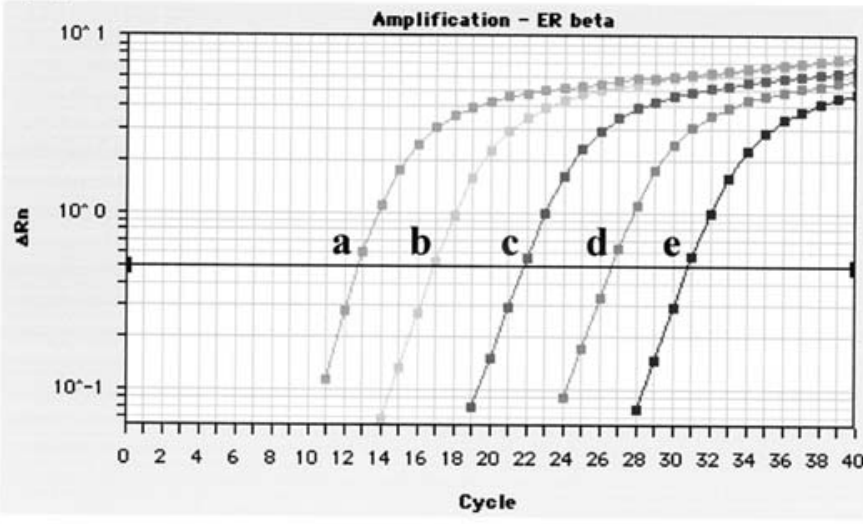

(B)

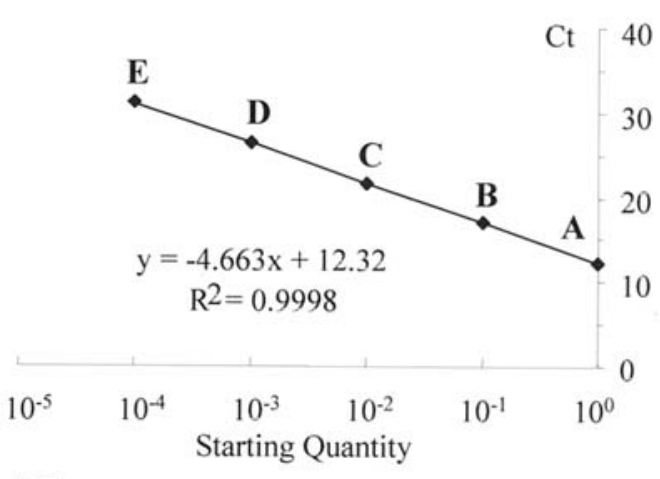

(D)

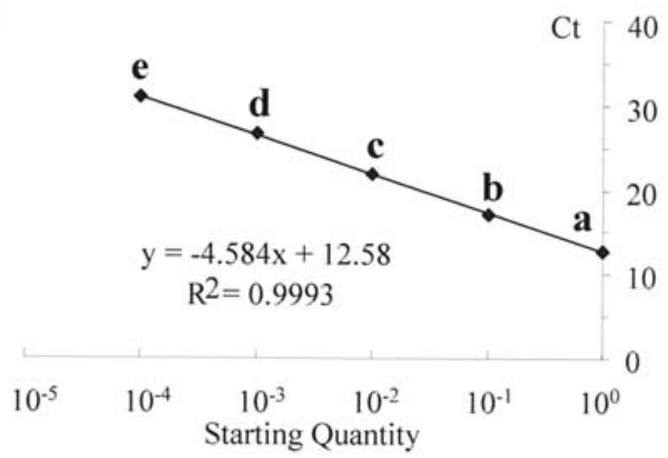

Figure 1. Standard curves of ER $\alpha$ and ERß mRNA quantification. Amplification plots for reactions with the five points of the ER $\alpha$ standard curve (10-fold serially diluted PCR products for ER $\alpha$; the original concentration is $4 \times 10^{8}$ copies/reaction mixture) (A). A standard curve plotting starting copy number vs. threshold cycle $(\mathrm{Ct})$ to determine the initial template concentration. Three replicates for each standard curve point were performed, but the data for only one are shown here (B). The amplification plots for reactions with the five points (C) and standard curve (D) for ERß, generated as described above (the original concentration is $5 \times 10^{8}$ copies/reaction mixture).

NY, USA) supplemented with $15 \%$ charcoal/dextran-stripped fetal bovine serum (HyClone, Logan, UT, USA) at least three days before experiments, until they reached $80 \%$ confluence. E2 (Wako Pure Chemical Industries, Ltd., Osaka, Japan) was dissolved in $100 \%$ ethanol and added to the medium at a final ethanol concentration of $0.1 \%$. Ethanol $(0.1 \%)$ was used as control.

Examination of E2 levels in culture media. After E2 was added to the culture media, E2 levels were examined using an electrochemiluminescence assay kit (Roche Diagnostic, Tokyo, Japan) to ensure coincidence with the calculated concentrations.

Normal endometrial tissue preparation. To validate the expression status of ER $\alpha$ and ERß in normal endometrium, 4 rice-ball sized normal endometrial specimens were obtained with informed consent from surgical tissues of patients diagnosed with early cervical cancer (average age, 39 years).

$R N A$ isolation, reverse transcription, and quantitative realtime PCR. Total RNA was isolated from the HHUA cells using an RNeasy mini kit (Qiagen, Valencia, CA, USA), and from the normal endometrial tissue using an RNeasy Protect mini kit (Qiagen). Total RNA samples were reverse transcribed into cDNA using TaqMan reverse transcription reagents (Applied Biosystems, Foster City, CA, USA). One microgram of each total RNA sample was added to a reverse transcriptase mixture, prepared in accordance with the TaqMan Gold RTPCR protocol, giving a final volume of $100 \mu \mathrm{l}$. The reverse transcription reactions were performed at $25^{\circ} \mathrm{C}$ for $10 \mathrm{~min}$, $37^{\circ} \mathrm{C}$ for $60 \mathrm{~min}$ and, finally, $95^{\circ} \mathrm{C}$ for $10 \mathrm{~min}$.

TaqMan quantitative real-time PCR was performed in a 50- $\mu 1$ reaction mixture on an ABI Prism 7700 sequence detector system (Applied Biosystems) according to the manufacturer's instructions, using appropriate primers and probes with a 6-carboxyfluorescein-labeled 3'-minor groove binder for the cDNAs encoding VEGF (Hs00173626_m1) and p53 (Hs00153340_m1) (Applied Biosystems). The primers and probes for Epo and Bcl-2 were synthesized according to previously published sequences $(10,20)$. The specificity of the PCR product was assessed by verifying a single peak in melting curve analysis. Based on the coincident PCR efficiency of the targets and endogenous reference, mRNA levels were normalized against an endogenous reference, $18 \mathrm{~S}$ rRNA (Applied Biosystems), and expressed as $2^{-\Delta \Delta C t}$ (21).

Preparation of the standards for absolute quantification of $E R \alpha$ and ERß mRNAs. The expression status of ER $\alpha$ and ERß mRNAs was compared using an external standard curve as 
(A)

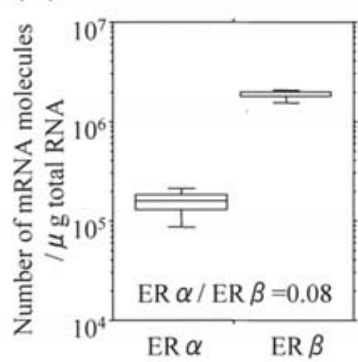

(C)

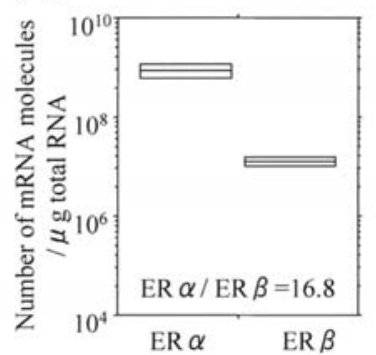

(D)

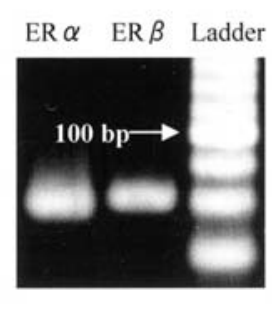

Figure 2. Comparison of ER $\alpha$ and ERß mRNA expression in HHUA cells and normal endometrial tissue. ER $\alpha$ and ERß mRNA levels were calculated as the molecule number per $1 \mu \mathrm{g}$ of total RNA extracted from each sample. Status of ER $\alpha$ and ERß mRNA expression in HHUA cells $(n=8)(A)$ is converse to that in normal endometrial tissue $(n=4)(C)$. RT-PCR products of ER $\alpha$ and ERß mRNAs in HHUA cells (B) and normal endometria (D) were electrophoresed on 3\% (w/v) agarose gels together with a 20-bp DNA ladder (Takara Bio. Inc., Tokyo, Japan), and stained with ethidium bromide. Product sizes: ER $\alpha, 62$ bp; ERß, 63 bp.

described previously (22). To prepare ER standards, PCR was performed using primers for ER $\alpha$ (Hs00174860_m1) and ERß (Hs00230957_m1) (Applied Biosystems). The PCR products were isolated after migration on agarose gel, purified using the QIAEX II gel extraction kit (Qiagen) and quantified by spectrophotometry. These reagents were then used as external standards to establish a standard curve and determine the number of ER $\alpha$ and ERß mRNA molecules in the experimental samples.

Immunocytochemistry. HHUA cells were cultured on chambered glass slides (Becton, Dickinson and Company) coated with collagen (Cellmatrix I-C, Nitta Gelatin Inc., Osaka, Japan). For immunostaining, the culture medium was removed, and the glass slides were washed with phosphate-buffered saline (PBS) and fixed with $10 \%$ formalin neutral buffer solution for $10 \mathrm{~min}$. The glass slides were then washed with PBS, incubated in $0.05 \%$ Tween 20-PBS for $10 \mathrm{~min}$, and blocked with $5 \%$ goat serum in $0.05 \%$ Tween 20 -PBS for $10 \mathrm{~min}$. The cells on glass slides were incubated overnight at $4^{\circ} \mathrm{C}$ with anti-human VEGF (Abcam plc., Tokyo, Japan) or anti-human Bcl-2 (Delta Biolabs, Campbell, CA, USA) rabbit IgG. After washing with $0.05 \%$ Tween 20 -PBS, incubation was continued for $1 \mathrm{~h}$ at room temperature with fluorescein isothiocyanate (FITC)-conjugated anti-rabbit IgG goat antibody (SouthernBiotech, Birmingham, AL, USA). Immunofluorescence images were observed under a fluorescence microscope (BX50; Olympus Corporation, Tokyo, Japan), using 470- to 490-nm excitation and 520- to 550-nm emission filters.

Statistics. Differences between groups were compared by a non-parametric Mann-Whitney U test using StatView software, version 5.0 (SAS Institute Inc., Cary, NC, USA). P $<0.05$ was considered to be statistically significant.

\section{Results}

ER $\alpha$ and ERß expression and the number of their transcripts in HHUA cells and normal endometria. ER $\alpha$ and ERß mRNA levels were calculated as the molecule number per $1 \mu \mathrm{g}$ of total RNA extracted from each sample. Real-time PCR was performed for $\mathrm{ER} \alpha$ and $\mathrm{ER} \beta$, and the molecule number was obtained using external standard curves (Fig. 1). Expression of ER $\alpha$ and ERß mRNAs was detectable in HHUA cells, with transcripts of ERß being much more abundant than those of $\mathrm{ER} \alpha$ (Fig. 2A). This pattern is the converse of the expression status detected in normal endometrial tissue (Fig. 2C). RT-PCR products of $\mathrm{ER} \alpha$ and $\mathrm{ER} \beta$ were validated by electrophoresis (Fig. 2B and D).

E2 affects VEGF and Bcl-2 mRNA expression in a timedependent manner. VEGF mRNA expression was elevated both in ethanol vehicle- and E2 $\left(10^{-8} \mathrm{M}\right)$-treated cells during a detecting period of $72 \mathrm{~h}$, with a higher expression level in ethanol vehicle-treated cells than in cells treated with E2 (Fig. 3A). Bcl-2 mRNA expression was decreased after E2 treatment compared with the ethanol control (Fig. 3C). A time-dependent expression tendency was not found for Epo (Fig. 3B) or p53 (Fig. 3D) under E2 induction.

E2 suppresses the expression of VEGF and Bcl-2 genes, but not Epo and p53 genes, in a dose-dependent manner. With the increment of E2 concentration from $10^{-10} \mathrm{M}$ to $10^{-6} \mathrm{M}$, the mRNA expression of VEGF and Bcl-2 was significantly inhibited (Fig. 4A and C) compared with that in ethanol vehicle-treated cells. No significant change in Epo (Fig. 4B) and p53 (Fig. 4D) expression was observed under E2 induction. Immunofluorescence for VEGF and Bcl-2 in ethanol vehicletreated cells was more prominent than that in the E2 $\left(10^{-8} \mathrm{M}\right)$ treated cells (Fig. 5).

\section{Discussion}

To date, many EC cell lines have been established. Among them, HHUA is reported as a rare cell line with ER expression, however, the expression status of ER subtypes has not been clear. In the present study, expression of both ER $\alpha$ and ERß was detectable in HHUA cells at the mRNA level, with the expression level of ERß being prominently higher than that of $E R \alpha$; however, results from previous studies consistently showed that the expression level of ER $\alpha$ was distinctively higher than that of ERß in normal endometria $(23,24)$, which was also demonstrated in the present study. Estrogen signaling is considered to be a dynamic balance between ER $\alpha$ and ERß (25), and each subtype has its own similar, but also unique and sometimes even opposing, responses to estrogen (26). The disrupted balance in the expression of these two subtypes of ER in HHUA cells is quite likely to cause the alteration of estrogen signaling pathways and, subsequently, regulation of the expression of related factors under E2 stimulation. 
(A)

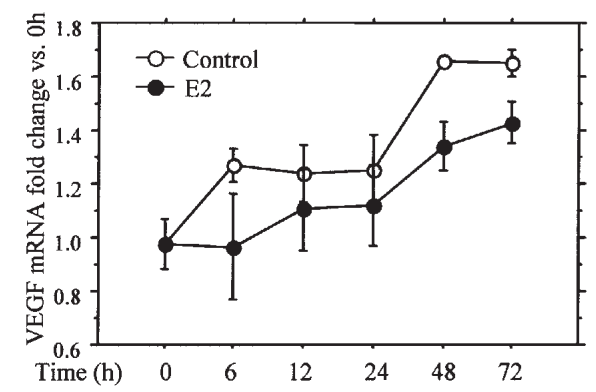

(C)

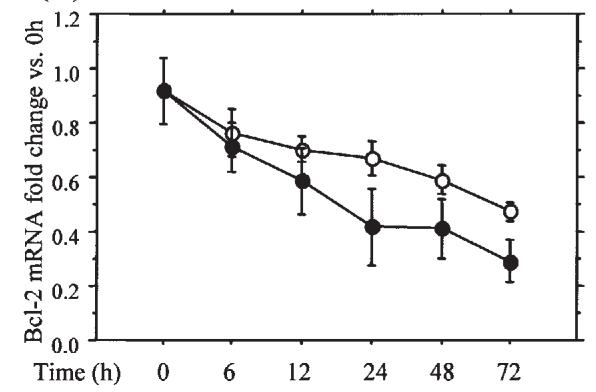

(B)

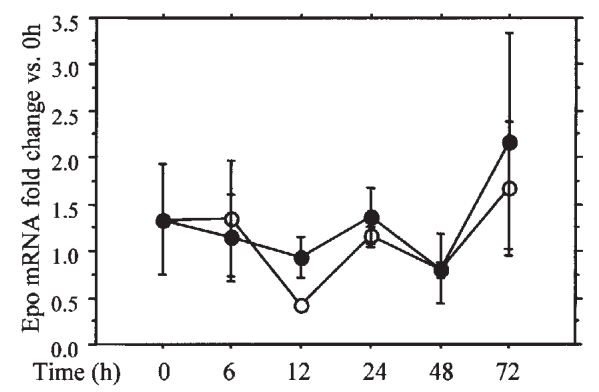

(D)

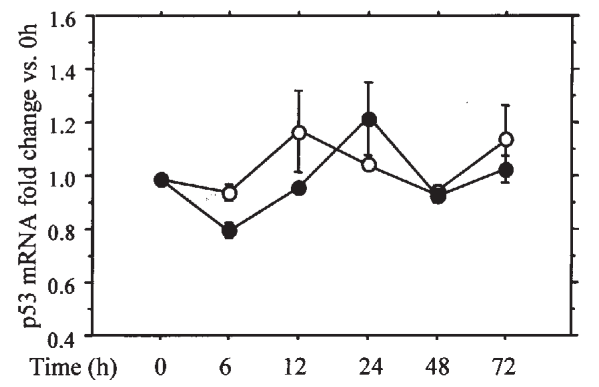

Figure 3. Time course effects of E2 on VEGF, Epo, Bcl-2 and p53 mRNA expression. The mRNA expression of VEGF (A), Epo (B), Bcl-2 (C) and p53 (D) was monitored by quantitative real-time RT-PCR. Cells were treated with $10^{-8} \mathrm{M}$ E2 dissolved in ethanol or ethanol vehicle for 6 , $12,24,48$ and $72 \mathrm{~h}$ ( $\mathrm{n}=4$ dishes per group and per time-point). Ethanol vehicle was used as a control. The mRNA levels were normalized against $18 \mathrm{~S}$ rRNA, as measured by real-time PCR. The values of mRNA level were then divided by that of the $0 \mathrm{~h}$ to produce fold changes.

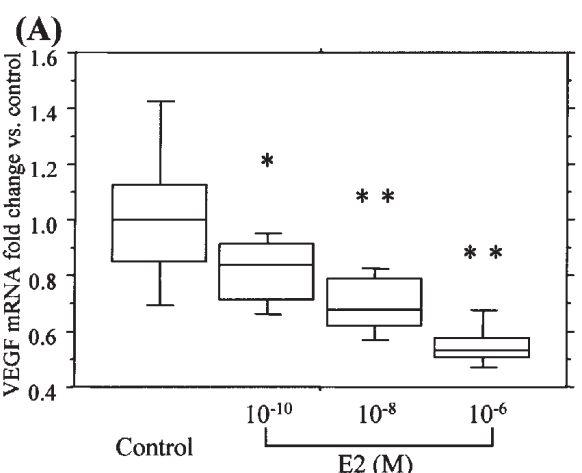

(C)

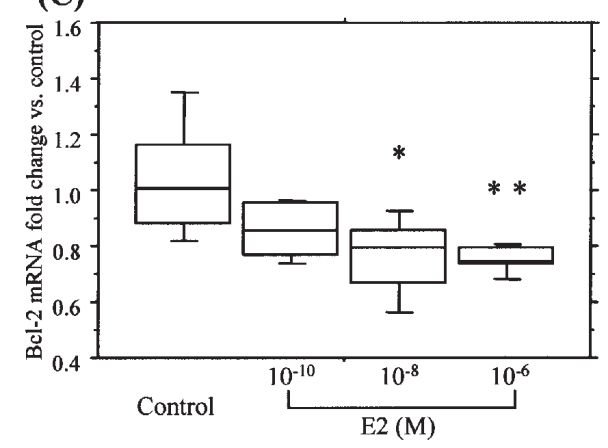

(B)

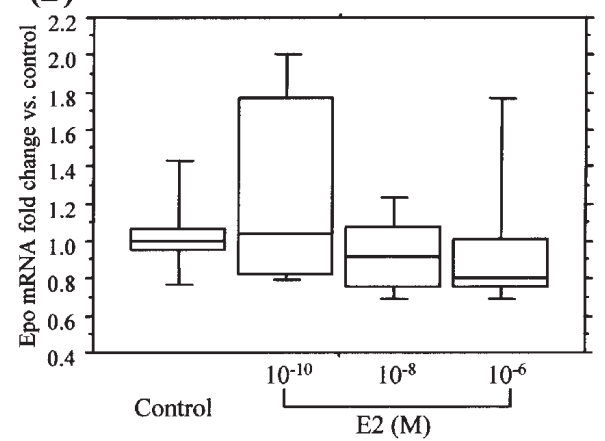

(D)

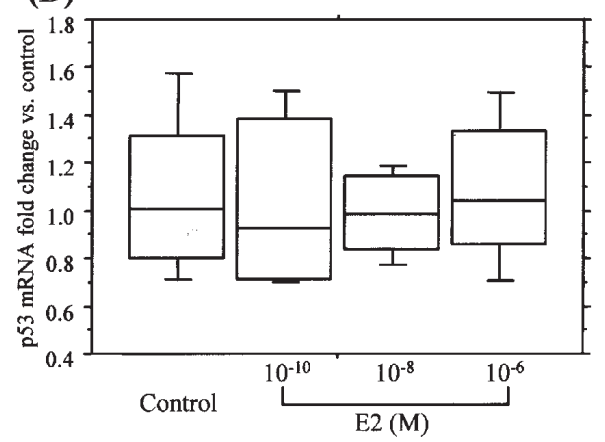

Figure 4. Dose effects of E2 on VEGF, Epo, Bcl-2 and p53 mRNA expression. The mRNA expression of VEGF (A), Epo (B), Bcl-2 (C) and p53 (D) was monitored by quantitative real-time RT-PCR. Cells were treated with $10^{-10}, 10^{-8}$, and $10^{-6} \mathrm{M}$ E2 dissolved in ethanol or ethanol vehicle for $48 \mathrm{~h}$ ( $\mathrm{n}=8 \mathrm{dishes}$ per group). Ethanol vehicle was used as a control. The mRNA levels were normalized against the level of $18 \mathrm{~S}$ rRNA, and divided by the control values to produce fold changes. The Mann-Whitney $\mathrm{U}$ test was employed to test the statistical significance of differences $\left({ }^{*} \mathrm{P}<0.05,{ }^{* *} \mathrm{P}<0.01\right)$.

Furthermore, loss of ER expression in ECs was suggested to correlate with advanced stages and a poor prognosis $(27,28)$. As a well-differentiated EC (19), HHUA cells are postulated to represent a transitional status of ER expression, prefiguring a preferential loss of ER $\alpha$ relative to ERß during the stepwise progression of EC, which underlies the characteristic molecular 

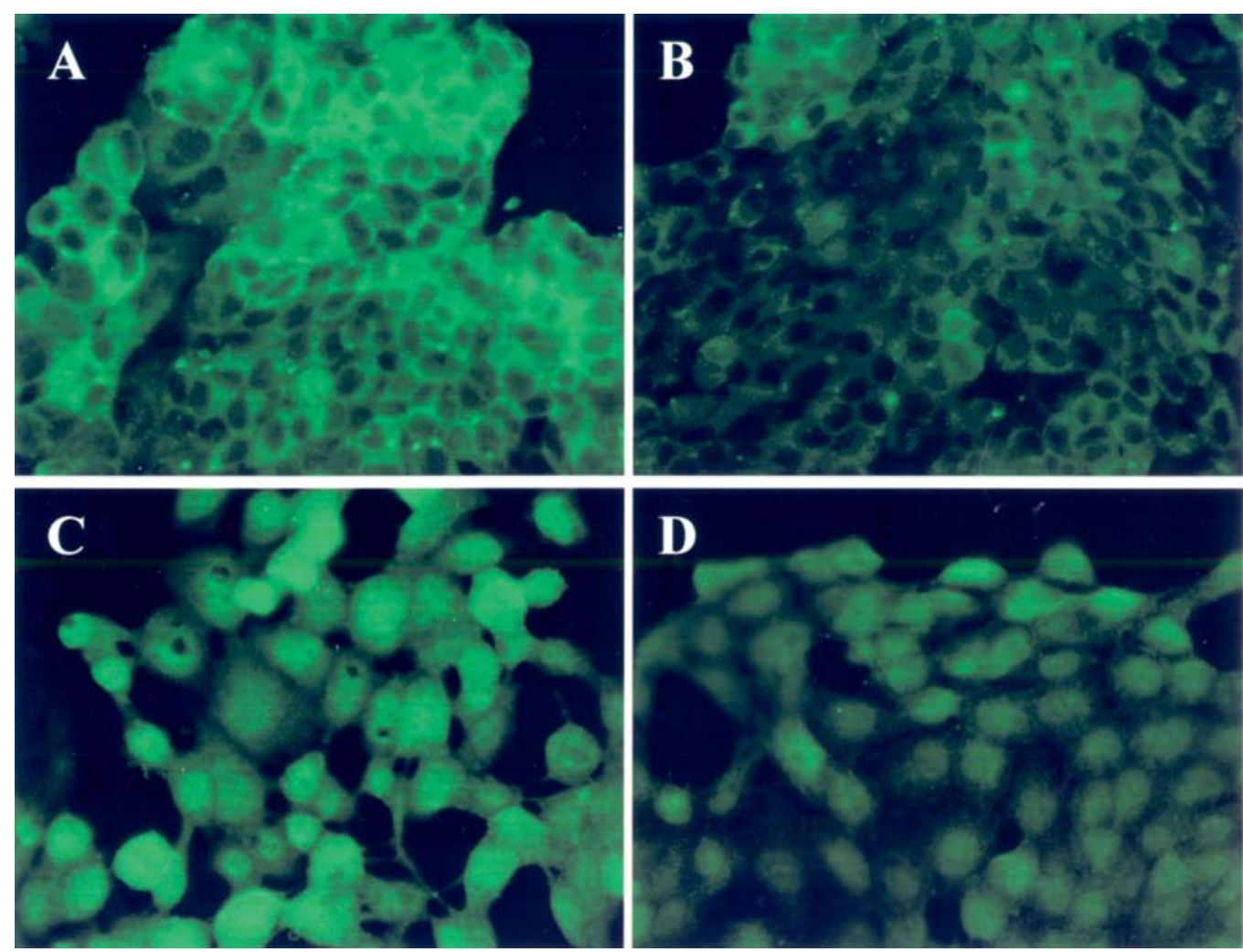

Figure 5. Fluorescence immunocytochemistry of VEGF and Bcl-2. HHUA cells treated with ethanol vehicle (A and C) or $10^{-8} \mathrm{M}$ E2 (B and D) for $48 \mathrm{~h}$ were fixed with 10\% formalin, reacted with anti-human VEGF (A and B), or anti-human Bcl-2 (C and D) rabbit IgG, and stained with FITC-conjugated anti-rabbit IgG antibody. The fluorescence for either VEGF or Bcl-2 was more prominent in the ethanol vehicle-treated cells than that in the E2-treated cells. Magnification, $\mathrm{x} 400$.

responses of HHUA cells to E2 compared with normal endometria and other EC cell lines.

Regarding the molecular mechanisms of VEGF expression, hypoxia is thought to be a common regulator in various normal and tumor tissue/cells in vivo. However, culturing cells in the present study under standard conditions (i.e. in 95\% air$5 \% \mathrm{CO}_{2}$, and thus $20 \% \mathrm{O}_{2}$ ) is not predicted to be affected by hypoxia (29). From the present study, we deemed that E2 suppresses VEGF expression in HHUA cells, without an effect of hypoxia. Previous studies showed that VEGF expression in ECs was estrogen-related (4-6). Moreover, it has been demonstrated that E2-regulated VEGF gene transcription requires a variant estrogen response element located $1.5 \mathrm{~kb}$ upstream from the transcriptional start site (30), and three potential estrogen signaling pathways, involving $\mathrm{ER} \alpha / \mathrm{ER} \alpha$ and $\mathrm{ER} \beta / \mathrm{ER} \beta$ homodimers, as well as $\mathrm{ER} \alpha / \mathrm{ER} \beta$ heterodimers, have been elucidated (31). Changes in the expression levels of the two subtypes may cause alterations in estrogen signaling pathways, which is possibly related to the regulation of VEGF under E2 induction in HHUA cells.

Epo is the best-known hypoxia-regulated gene, with a mechanism of regulation by hypoxia similar to that for VEGF gene expression (32). For the reasons mentioned above, the hypoxia-regulated pathway is regarded of no significance to the Epo expression observed in the present cell culture study, and E2 showed no regulative effects on the Epo expression in HHUA cells cultured in normoxia.

Bcl-2 and p53 were chosen for analysis in the present study as two apoptosis-related factors. The results showed that the expression of Bcl-2 was suppressed by E2; however, there were no significant changes in the levels of p53. We also counted the cell number after stimulation of cells with E2 for $48 \mathrm{~h}$. The number of HHUA cells increased significantly under treatment of $10^{-8} \mathrm{M}$ and $10^{-10} \mathrm{M}$ E2 compared with ethanol vehicle control (data not shown). In fact, a number of immunohistochemical studies have also shown such contrary results (33-35), despite the consideration that $\mathrm{Bcl}-2$ is generally thought to be more highly expressed in EC than in normal endometrium, and in higher histologic grades than lower grades. It has been reported that $\mathrm{Bcl}-2$ expression in EC is under estrogen control via the ER (33). With respect to this, the abnormal expression of ER $\alpha$ and ER $\beta$ in HHUA cells might be associated with Bcl-2 expression under E2 stimulation.

In conclusion, the present study shows the expression of VEGF, Epo, Bcl-2 and p53 in HHUA cells, and the downregulated expression of VEGF and Bcl-2 under E2 induction. Furthermore, we demonstrate for the first time that both $\mathrm{ER} \alpha$ and ERß mRNAs are detectable in HHUA cells, and that the pattern of $E R \alpha$ and $E R B$ expression is converse to that in normal endometria; this expression pattern should be taken into consideration to understand the particularity of E2-regulated gene expression in HHUA cells.

\section{Acknowledgments}

We would like to thank all of the gynecologists at Osaka City University Graduate School of Medicine for their support. 


\section{References}

1. Bergers $\mathrm{G}$ and Benjamin LE: Tumorigenesis and the angiogenic switch. Nat Rev Cancer 3: 401-410, 2003.

2. Carmeliet P: VEGF as a key mediator of angiogenesis in cancer. Oncology 69 (suppl 3): 4-10, 2005.

3. Keck PJ, Hauser SD, Krivi G, Sanzo K, Warren T, Feder J and Connolly DT: Vascular permeability factor, an endothelial cell mitogen related to PDGF. Science 246: 1309-1312, 1989.

4. Stoner M, Wang F, Wormke M, Nguyen T, Samudio I, Vyhlidal C, Marme D, Finkenzeller G and Safe S: Inhibition of vascular endothelial growth factor expression in HEC1A endometrial cancer cells through interactions of estrogen receptor alpha and Sp3 proteins. J Biol Chem 275: 22769-22779, 2000.

5. Archer DF, Navarro FJ, Leslie S and Mirkin S: Effects of levonorgestrel, medroxyprogesterone acetate, norethindrone, and 17 beta-estradiol on vascular endothelial growth factor isomers 121 and 165 in Ishikawa cells. Fertil Steril 81: 165-170, 2004.

6. Seo KH, Lee HS, Jung B, Ko HM, Choi JH, Park SJ, Choi IH, Lee HK and Im SY: Estrogen enhances angiogenesis through a pathway involving platelet-activating factor-mediated nuclear factor-kappaB activation. Cancer Res 64: 6482-6488, 2004.

7. Ribatti D, Vacca A, Roccaro AM, Crivellato E and Presta M: Erythropoietin as an angiogenic factor. Eur J Clin Invest 33: 891-896, 2003

8. Schuster SJ, Koury ST, Bohrer M, Salceda S and Caro J: Cellular sites of extrarenal and renal erythropoietin production in anaemic rats. Br J Haematol 81: 153-159, 1992

9. Yasuda Y, Masuda S, Chikuma M, Inoue K, Nagao M and Sasaki R: Estrogen-dependent production of erythropoietin in uterus and its implication in uterine angiogenesis. J Biol Chem 273: 25381-25387, 1998

10. Yokomizo R, Matsuzaki S, Uehara S, Murakami T, Yaegashi N and Okamura K: Erythropoietin and erythropoietin receptor expression in human endometrium throughout the menstrual cycle. Mol Hum Reprod 8: 441-446, 2002.

11. Acs G, Xu X, Chu C, Acs P and Verma A: Prognostic significance of erythropoietin expression in human endometrial carcinoma. Cancer 100: 2376-2386, 2004.

12. Yasuda Y, Fujita Y, Masuda S, Musha T, Ueda K, Tanaka H, Fujita H, Matsuo T, Nagao M, Sasaki R and Nakamura Y: Erythropoietin is involved in growth and angiogenesis in malignant tumours of female reproductive organs. Carcinogenesis 23: 1797-1805, 2002

13. Tsujimoto Y, Finger LR, Yunis J, Nowell PC and Croce CM: Cloning of the chromosome breakpoint of neoplastic B cells with the $\mathrm{t}(14 ; 18)$ chromosome translocation. Science 226 1097-1099, 1984.

14. Williams GT: Programmed cell death: apoptosis and oncogenesis. Cell 65: 1097-1098, 1991

15. Gompel A, Sabourin JC, Martin A, Yaneva H, Audouin J, Decroix $\mathrm{Y}$ and Poitout $\mathrm{P}$ : Bcl-2 expression in normal endometrium during the menstrual cycle. Am J Pathol 144: 1195-1202, 1994.

16. Otsuki Y, Misaki O, Sugimoto O, Ito Y, Tsujimoto Y and Akao Y: Cyclic bcl-2 gene expression in human uterine endometrium during menstrual cycle. Lancet 344: 28-29, 1994.

17. Haldar S, Negrini M, Monne M, Sabbioni S and Croce CM: Down-regulation of bcl-2 by p53 in breast cancer cells. Cancer Res 54: 2095-2097, 1994.

18. Nakamura S, Akazawa K, Kinukawa N, Yao T and Tsuneyoshi M: Inverse correlation between the expression of bcl-2 and p53 proteins in primary gastric lymphoma. Hum Pathol 27: 225-233, 1996.

19. Ishiwata I, Ishiwata C, Soma M, Arai J and Ishikawa H: Establishment of human endometrial adenocarcinoma cell line containing estradiol-17 beta and progesterone receptors. Gynecol Oncol 17: 281-290, 1984.
20. Shimizu D, Vallbohmer D, Kuramochi H, Uchida K, Schneider S, Chandrasoma PT, Shimada H, DeMeester TR, Danenberg KD, Peters JH, DeMeester SR and Danenberg PV: Increasing cyclooxygenase-2 (cox-2) gene expression in the progression of Barrett's esophagus to adenocarcinoma correlates with that of Bcl-2. Int J Cancer 119: 765-770, 2006.

21. Yuan JS, Reed A, Chen F and Stewart CN Jr: Statistical analysis of real-time PCR data. BMC Bioinformatics 7: 85, 2006.

22. Nancy P and Berrih-Aknin S: Differential estrogen receptor expression in autoimmune myasthenia gravis. Endocrinology 146: 2345-2353, 2005.

23. Pelletier G and El-Alfy M: Immunocytochemical localization of estrogen receptors alpha and beta in the human reproductive organs. J Clin Endocrinol Metab 85: 4835-4840, 2000.

24. Matsuzaki S, Fukaya T, Suzuki T, Murakami T, Sasano H and Yajima A: Oestrogen receptor alpha and beta mRNA expression in human endometrium throughout the menstrual cycle. Mol Hum Reprod 5: 559-564, 1999.

25. Matthews $\mathbf{J}$ and Gustafsson JA: Estrogen signaling: a subtle balance between ER alpha and ER beta. Mol Interv 3: 281-292, 2003

26. Paech K, Webb P, Kuiper GG, Nilsson S, Gustafsson J, Kushner PJ and Scanlan TS: Differential ligand activation of estrogen receptors ERalpha and ERbeta at AP1 sites. Science 277: 1508-1510, 1997.

27. Pertschuk LP, Masood S, Simone J, Feldman JG, Fruchter RG, Axiotis CA and Greene GL: Estrogen receptor immunocytochemistry in endometrial carcinoma: a prognostic marker for survival. Gynecol Oncol 63: 28-33, 1996.

28. Li SF, Shiozawa T, Nakayama K, Nikaido T and Fujii S Stepwise abnormality of sex steroid hormone receptors, tumor suppressor gene products ( 553 and $\mathrm{Rb}$ ), and cyclin $\mathrm{E}$ in uterine endometrioid carcinoma. Cancer 77: 321-329, 1996.

29. Kazi AA, Jones JM and Koos RD: Chromatin immunoprecipitation analysis of gene expression in the rat uterus in vivo: estrogen-induced recruitment of both estrogen receptor alpha and hypoxia-inducible factor 1 to the vascular endothelial growth factor promoter. Mol Endocrinol 19: 2006-2019, 2005

30. Mueller MD, Vigne JL, Minchenko A, Lebovic DI, Leitman DC and Taylor RN: Regulation of vascular endothelial growth factor (VEGF) gene transcription by estrogen receptors alpha and beta. Proc Natl Acad Sci USA 97: 10972-10977, 2000.

31. Kuiper GG and Gustafsson JA: The novel estrogen receptorbeta subtype: potential role in the cell- and promoter-specific actions of estrogens and anti-estrogens. FEBS Lett 410: 87-90, 1997

32. Liu Y, Cox SR, Morita T and Kourembanas S: Hypoxia regulates vascular endothelial growth factor gene expression in endothelial cells. Identification of a 5' enhancer. Circ Res 77: 638-643, 1995.

33. Yamauchi N, Sakamoto A, Uozaki H, Iihara K and Machinami R: Immunohistochemical analysis of endometrial adenocarcinoma for bcl-2 and p53 in relation to expression of sex steroid receptor and proliferative activity. Int J Gynecol Pathol 15: 202-208, 1996.

34. Mitselou A, Ioachim E, Kitsou E, Vougiouklakis T, Zagorianakou N, Makrydimas G, Stefanaki S and Agnantis NJ: Immunohistochemical study of apoptosis-related Bcl-2 protein and its correlation with proliferation indices (Ki67, PCNA), tumor suppressor genes (p53, pRb), the oncogene c-erbB-2, sex steroid hormone receptors and other clinicopathological features, in normal, hyperplastic and neoplastic endometrium. In Vivo 17: 469-477, 2003.

35. Henderson GS, Brown KA, Perkins SL, Abbott TM and Clayton F: bcl-2 is down-regulated in atypical endometrial hyperplasia and adenocarcinoma. Mod Pathol 9: 430-438, 1996. 